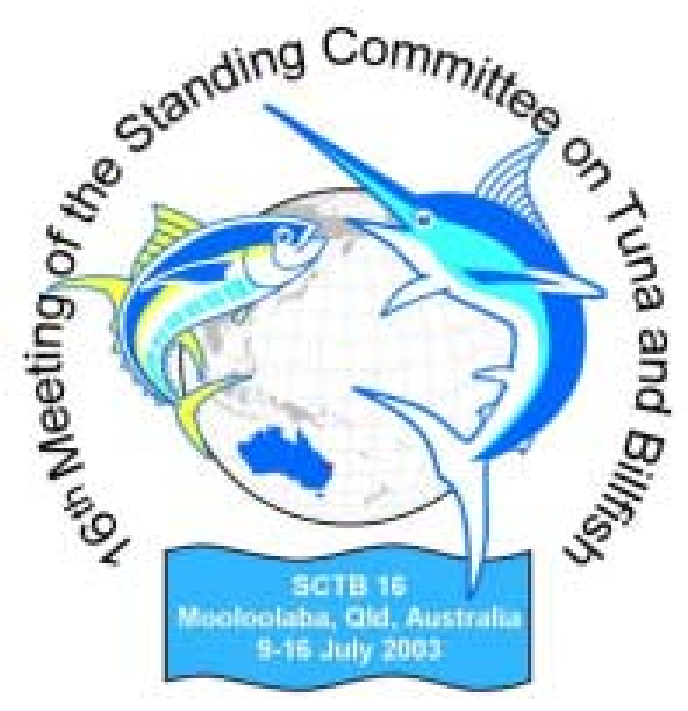

SCTB16 Working Paper

SKJ-9

\title{
Daily increment formation in otoliths of juvenile skipjack tuna Katsuwonus pelamis
}

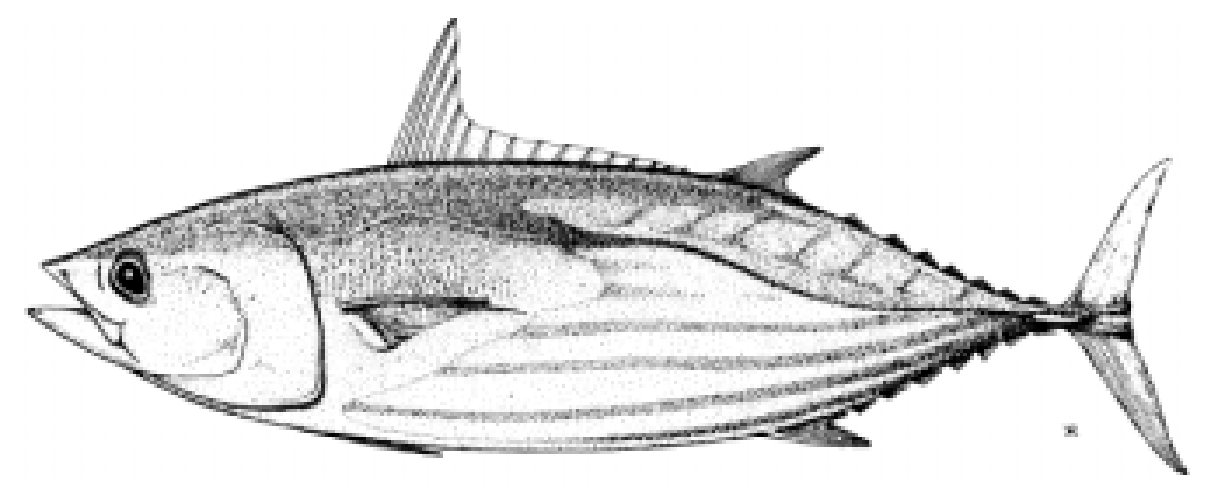

T. Tanabe, S. Kayama, M. Ogura and S. Tanaka

National Research Institute of Far Seas Fisheries

Japan

July 2003 


\title{
Daily increment formation in otoliths of juvenile skipjack tuna Katsuwonus pelamis
}

\author{
ToshiYuki TANABE, ${ }^{1 *}$ SADAAKI KAYAMA, ${ }^{2 \dagger}$ Miki OGURA ${ }^{1}$ AND Sho TANAKA ${ }^{2}$ \\ ${ }^{1}$ National Research Institute of Far Seas Fisheries, Shimizu, Shizuoka 424-8633 and ${ }^{2}$ School of \\ Marine Science and Technology, Tokai University, Shimizu, Shizuoka 424-8610, Japan
}

\begin{abstract}
In the present study, we verified daily increment formation within sagittal otoliths of juvenile skipjack tuna Katsuwonus pelamis by analysis of diel changes in marginal increment width. Specimens were collected by midwater trawl in the tropical western Pacific from November to December 1995 and in February 1999. The sagittal plane of the otolith was embedded in enamel resin and polished with lapping films. The otolith-measuring system was equipped with a light microscope and was used for marginal increment analysis. The index of completion of the marginal increment increased with time of day, approximately $40 \%$ at $07: 00-10: 00 \mathrm{~h}, 66 \%$ at $13: 00-16: 00 \mathrm{~h}$ and $80 \%$ at 19:00-23:00 h. Therefore, growth of the marginal increment progressed from morning to evening and was completed during the night. We conclude that increments are formed daily in juvenile skipjack otoliths and these increments have a width of $15-40 \mu \mathrm{m}$.
\end{abstract}

KEY WORDS: daily increment, juvenile, marginal growth, otolith, skipjack tuna.

\section{INTRODUCTION}

Clarification of the age-growth relationship of marine fish is basic information for the assessment and management of fishery resources. Studies on the growth of marine fish using daily otolith increments have rapidly developed in recent years and have contributed to the progress in the assessment of fishery resources. ${ }^{1-8}$ Utilization of a precise and reliable aging structure is necessary for age determination; however, the formation of daily growth increments in otoliths should be verified for age and growth estimates.

Three reports have examined the periodicity of increment formation in otoliths of larval or adult skipjack tuna Katsuwonus pelamis. ${ }^{9-11}$ Radtke $^{9}$ validated daily periodicity in increment deposition during the first 5 days after hatching in larval skipjack tuna. Uchiyama and Struhsaker ${ }^{10}$ studied increment formation in adult skipjack by counting growth increments that were formed during a normal feeding period with check marks that were deposited during a starvation period. However, the

${ }^{*}$ Corresponding author: Tel: 81-543-36-6033.

Fax: 81-543-35-9642. Email: katsuwo@affrc.go.jp

†Present address: Ocean Research Institute, The University of Tokyo, Nakano, Tokyo 164-8639, Japan.

Received 11 March 2002. Accepted 5 February 2003. authors described the daily increment validation results as inconclusive. They examined only four individuals in the experiment and the number of increments was larger than the expected days in all fish examined. The authors pointed out the necessity for further experiments performed under precise conditions. Wild et al. ${ }^{11}$ also studied the periodicity of increment deposition in adult skipjack tuna. The otoliths of experimental fish were marked with oxytetracycline at the time of release and the number of increments that were formed during the duration between mark and recapture were counted. Results indicated a deposition rate of 0.7 increments per day. The authors hypothesized that increments were not deposited daily due to: (i) resolution difficulties in counting increments, which results in an underestimation of the actual number of days; and (ii) physiological factors, such as the maturation of females, which negatively affects increment deposition.

Daily increment formation is commonly recognized in the otoliths of many marine species, but previous studies indicate a non-daily deposition rate in adult skipjack otoliths.

Our observations of skipjack otoliths indicate that increments formed during the juvenile stage are obviously different in morphological structure in comparison with the larval stage, as illustrated by Radtke. ${ }^{9}$ Increment width increases and the structure was more complicated. Given the diffi- 
culties in enumerating post-larval increments in otoliths, we have conducted a precise examination of increment formation in otoliths of juvenile skipjack. This study is a part of an age and growth study of skipjack tuna in the western Pacific Ocean. In the present study, we measured the marginal growth of sagittal otoliths of juvenile skipjack tuna collected at various times of days and verified the formation of daily growth increments.

\section{MATERIALS AND METHODS}

\section{Skipjack specimens}

Juvenile skipjack tuna were collected in the tropical western Pacific from November to December 1995 and February 1999 (Fig. 1). A midwater trawl net was used for sampling skipjack. ${ }^{12}$ Maximum towing speed and the mouth opening of the net were approximately 5 knots and $20 \times 20 \mathrm{~m}$, respectively. Trawling activities were conducted from $06: 00$ to $00: 00 \mathrm{~h}$. Specimens were immediately preserved in $80 \%$ ethanol on the research vessel and then taken to the laboratory. During 1995, trawling operations were conducted four times a day at 20 sampling stations and a total of 122 juvenile skipjack tuna from four locations (seven tows) were used in the analysis (Table 1). During 1999, trawling operations were conducted for 2 days at only one location and a total of 72 juveniles from eight tows were used. Specimens used in the marginal increment analysis were selected randomly from the individual collections.

\section{Otolith analysis}

Standard length (SL) of the juvenile skipjack tuna was measured to the nearest $0.1 \mathrm{~mm}$ and the sagittal otoliths were removed under a dissecting microscope. Fibrous tissues were removed with sharpened needles and the otoliths were cleaned. Otoliths were soaked in distilled water on a slide

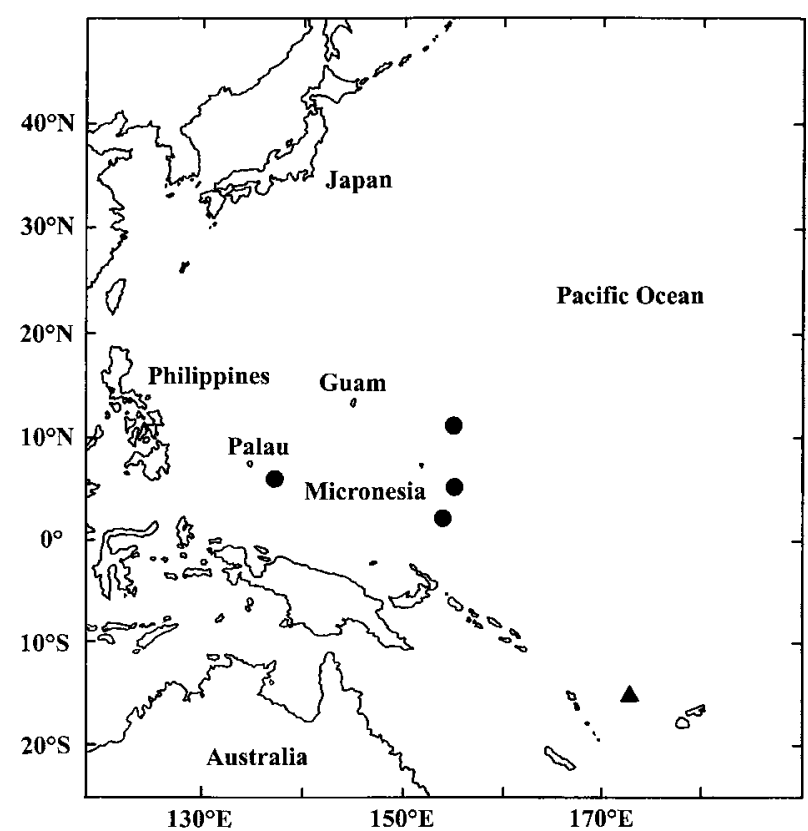

Fig. 1 Sampling locations of juvenile skipjack tuna used for the otolith marginal increment analysis in 1995 (O) and $1999(\mathbf{\Delta})$ cruises.

Table 1 Data for juvenile skipjack tuna specimens used for marginal increment analysis of sagittal otoliths

\begin{tabular}{|c|c|c|c|c|c|c|}
\hline \multirow[b]{2}{*}{ Date } & \multirow[b]{2}{*}{ Time (h) } & \multicolumn{2}{|c|}{ Location } & \multirow{2}{*}{$\begin{array}{l}\text { No. juvenile } \\
\text { otoliths used }\end{array}$} & \multicolumn{2}{|c|}{ SL (mm) } \\
\hline & & Latitude & Longitude & & Minimum & Maximum \\
\hline \multicolumn{7}{|l|}{1995} \\
\hline 4 November & $14: 20$ & $5^{\circ} 59^{\prime} \mathrm{N}$ & $137^{\circ} 17^{\prime} \mathrm{E}$ & 14 & 18.6 & 25.5 \\
\hline 25 November & $22: 30$ & $1^{\circ} 56^{\prime} \mathrm{N}$ & $154^{\circ} 02^{\prime} \mathrm{E}$ & 28 & 18.6 & 39.8 \\
\hline 26 November & $08: 35$ & $1^{\circ} 57^{\prime} \mathrm{N}$ & $154^{\circ} 03^{\prime} \mathrm{E}$ & 19 & 16.8 & 28.6 \\
\hline 27 November & $13: 05$ & $4^{\circ} 54^{\prime} \mathrm{N}$ & $154^{\circ} 56^{\prime} \mathrm{E}$ & 10 & 12.9 & 21.0 \\
\hline 27 November & $20: 00$ & $4^{\circ} 54^{\prime} \mathrm{N}$ & $154^{\circ} 55^{\prime} \mathrm{E}$ & 11 & 17.5 & 28.8 \\
\hline 3 December & $20: 45$ & $11^{\circ} 00^{\prime} \mathrm{N}$ & $155^{\circ} 00^{\prime} \mathrm{E}$ & 19 & 13.5 & 29.8 \\
\hline 4 December & $07: 05$ & $11^{\circ} 00^{\prime} \mathrm{N}$ & $154^{\circ} 59^{\prime} \mathrm{E}$ & 21 & 12.9 & 32.8 \\
\hline \multicolumn{7}{|l|}{1999} \\
\hline 6 February & $14: 10$ & $15^{\circ} 04^{\prime} \mathrm{S}$ & $173^{\circ} 00^{\prime} \mathrm{E}$ & 10 & 20.8 & 32.7 \\
\hline 6 February & $15: 35$ & $15^{\circ} 00^{\prime} \mathrm{S}$ & $173^{\circ} 00^{\prime} \mathrm{E}$ & 8 & 25.6 & 30.9 \\
\hline 6 February & $20: 25$ & $15^{\circ} 03^{\prime} \mathrm{S}$ & $173^{\circ} 00^{\prime} \mathrm{E}$ & 11 & 23.0 & 34.2 \\
\hline 7 February & $08: 00$ & $14^{\circ} 59^{\prime} \mathrm{S}$ & $173^{\circ} 00^{\prime} \mathrm{E}$ & 6 & 20.8 & 34.3 \\
\hline 7 February & $09: 25$ & $15^{\circ} 03^{\prime} \mathrm{S}$ & $173^{\circ} 00^{\prime} \mathrm{E}$ & 10 & 24.2 & 31.3 \\
\hline 7 February & $13: 05$ & $15^{\circ} 00^{\prime} \mathrm{S}$ & $173^{\circ} 00^{\prime} \mathrm{E}$ & 8 & 24.7 & 32.2 \\
\hline 7 February & $19: 05$ & $15^{\circ} 00^{\prime} \mathrm{S}$ & $173^{\circ} 00^{\prime} \mathrm{E}$ & 10 & 23.2 & 32.2 \\
\hline 7 February & $21: 55$ & $15^{\circ} 00^{\prime} \mathrm{S}$ & $172^{\circ} 59^{\prime} \mathrm{E}$ & 9 & 26.2 & 33.2 \\
\hline
\end{tabular}


glass and then dried at ambient temperature. An otolith was embedded in enamel resin (Overcoat NA; Shiseido, Tokyo, Japan) on a clear microscope slide. The mounted otolith was allowed to set for $48 \mathrm{~h}$; thereafter, the proximal side of the otolith was polished with lapping films at grit sizes of 9, 3 and $1 \mu \mathrm{m}$. The enamel resin was dissolved with a few drops of solvent and the otolith was turned over. After the otolith was mounted again, the distal side was also polished with the same procedure. During the polishing process, the appearance of increments was observed under a light microscope (LM). The polishing procedure was finished when the increments between the core and the edge along the growth axis could be observed. The polished surface was covered with enamel resin to protect it from dust.

The number of increments between the core and the edge was counted and increment widths were measured using an otolith-measurement system (ARP/W; Ratoc System Engineering, Tokyo, Japan). The otolith radius was measured as the maximum length between the core and the posterior edge. The system was composed of an LM (BX60-33; Olympus Optical, Tokyo, Japan), chargecoupled device (CCD)-camera (CS-580; Olympus Optical) and a personal computer. The magnification of the LM was $500 \times$ or $1000 \times$.

An index of completion of the marginal increment was calculated with the following equation: ${ }^{13}$

$$
C=W_{n} /\left(\left(W_{n-1}+W_{n-2}\right) / 2\right) \times 100
$$

where $W_{n}$ is width of the marginal increment and $W_{n-1}$ and $W_{n-2}$ are widths of the previous complete increments that exist prior to the marginal increment.

We estimated the periodicity of increment formation by changes in the index of completion during the time of day.

\section{RESULTS}

\section{Otolith microstructure}

A growth increment consisted of an optically transparent zone and dense zone, when observed under a LM with transmitted light (Fig. 2). These two bands were formed alternately and were deposited regularly. They were equivalent to the accretion zone and the discontinuous zone, respectively. ${ }^{14}$ The core existed in the central region of the sagittal plane and was observed as a dark structure. The initial fifth to seventh increments were usually deposited in a round shape and the width of each increment was narrow $(2-4 \mu \mathrm{m})$. The width of the fifth to 10th increments gradually increased from 5
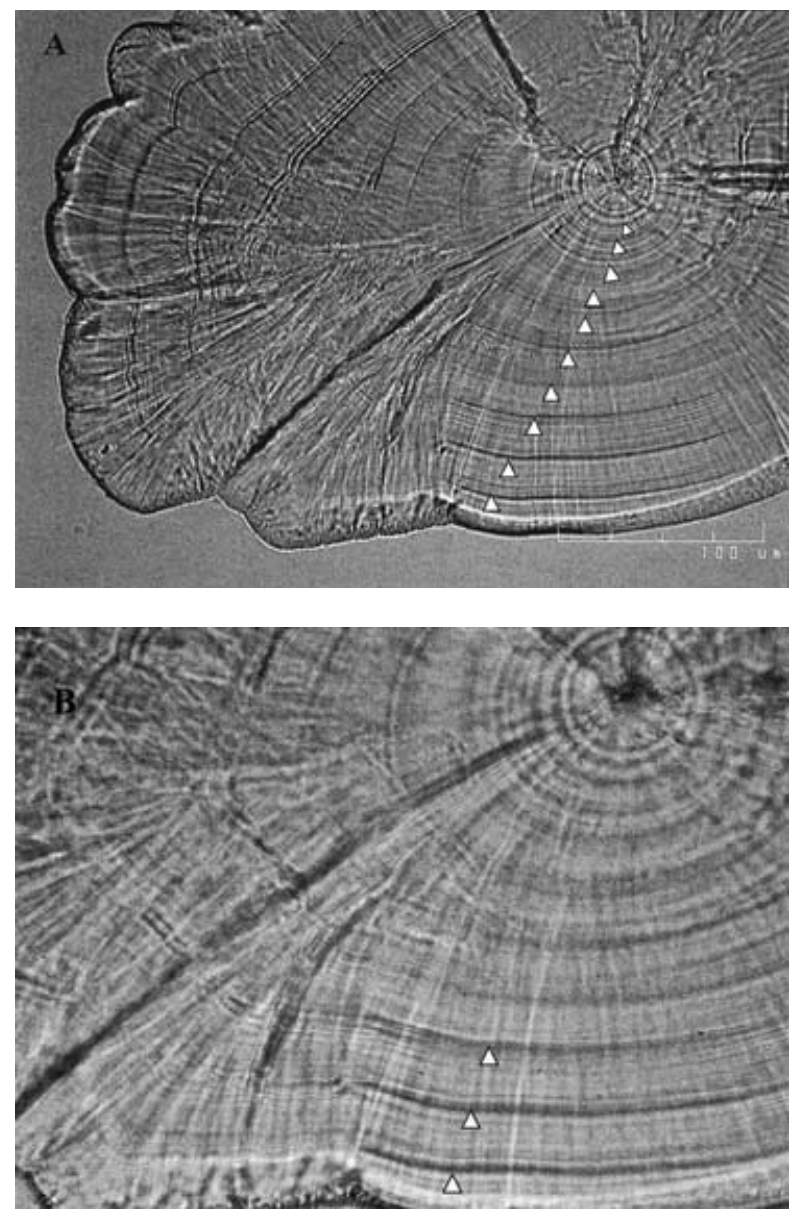

Fig. 2 Transmitted light micrograph of a sagittal otolith from a $29.8 \mathrm{~mm}$ standard length juvenile skipjack Katsuwonus pelamis. The number of daily increments counted with the otolith measurement system was 15 . (a) The discontinuous zone (arrowhead) of the fifth to 14th increments, which illustrates the outer edge of a daily increment. (b) Subdaily increments existed within the 12th to 14th daily increments (arrowhead) and can disappear when slightly changing the focus of the microscope.

to $15 \mu \mathrm{m}$ and the increments became oval in shape, which was caused by an extension along the rostrum-post-rostrum axis. Increment width ranged from 15 to $40 \mu \mathrm{m}$ along the growth axis after the 10th increment.

Subdaily increments existed in all otoliths examined. The discrimination of daily increments from subdaily increments was performed by observing the clearness of the increment; that is, daily increments have a distinctly dark discontinuous zone, whereas subdaily increments disappeared when slightly changing the focus of the LM (Fig. 2). The number of subdaily increments per daily increment increased with an increase in daily increment 
width. Fewer than five subdaily increments were usually observed from the fifth to 10th daily increments and five to eight subdaily increments existed after the 10th daily increment. The periodicity of subdaily increment deposition was not estimated in the present study.

It was difficult to observe increments in otoliths from larger juveniles because of the increasing thickness of the frontal plane. The maximum fish size that we could resolve increments using this method was $60 \mathrm{~mm}$ SL (S Kayama, unpubl. data, 2001). The visibility of growth increments differed markedly between individual otoliths.

\section{Diel change in the index of completion of the marginal increment}

The index of completion of the marginal increment changed with the time of day in both the 1995 and 1999 samples (Fig. 3). The index increased from morning, afternoon and evening. The index averaged $40 \%$ (range 15.4-74.7\%) in the morning $(07: 00-10: 00 \mathrm{~h}), 66 \%$ (range 30.9$107.0 \%)$ in the afternoon (13:00-16:00 h) and 80\% (range 82.6-110.6\%) in the evening (19:00$23: 00 \mathrm{~h}$ ). These changes in the growth of the marginal increment from morning, afternoon and evening were highly significant $(P<0.001, t$-test $)$ and those from afternoon to evening were also significant $(P<0.05)$.

A portion of samples collected in 1995 included one individual at $20: 00 \mathrm{~h}$ and two individuals at $22: 30 \mathrm{~h}$ that already had completed the marginal increment and had the next increment beginning to form.

\section{Number of increments and relation to SL}

The size of juvenile skipjack tuna ranged from 12.9 to $39.8 \mathrm{~mm}$ SL and the number of daily increments observed in the present study ranged from 12 to 19 . The mode of daily increments was 14 in 1995 and 17 in 1999. A positive linear relationship between the number of daily increments and SL was evident (Fig. 4). The daily growth rate or slope of the linear regression line was $2.8 \mathrm{~mm} /$ day in 1995 and $1.7 \mathrm{~mm} /$ day in 1999 .
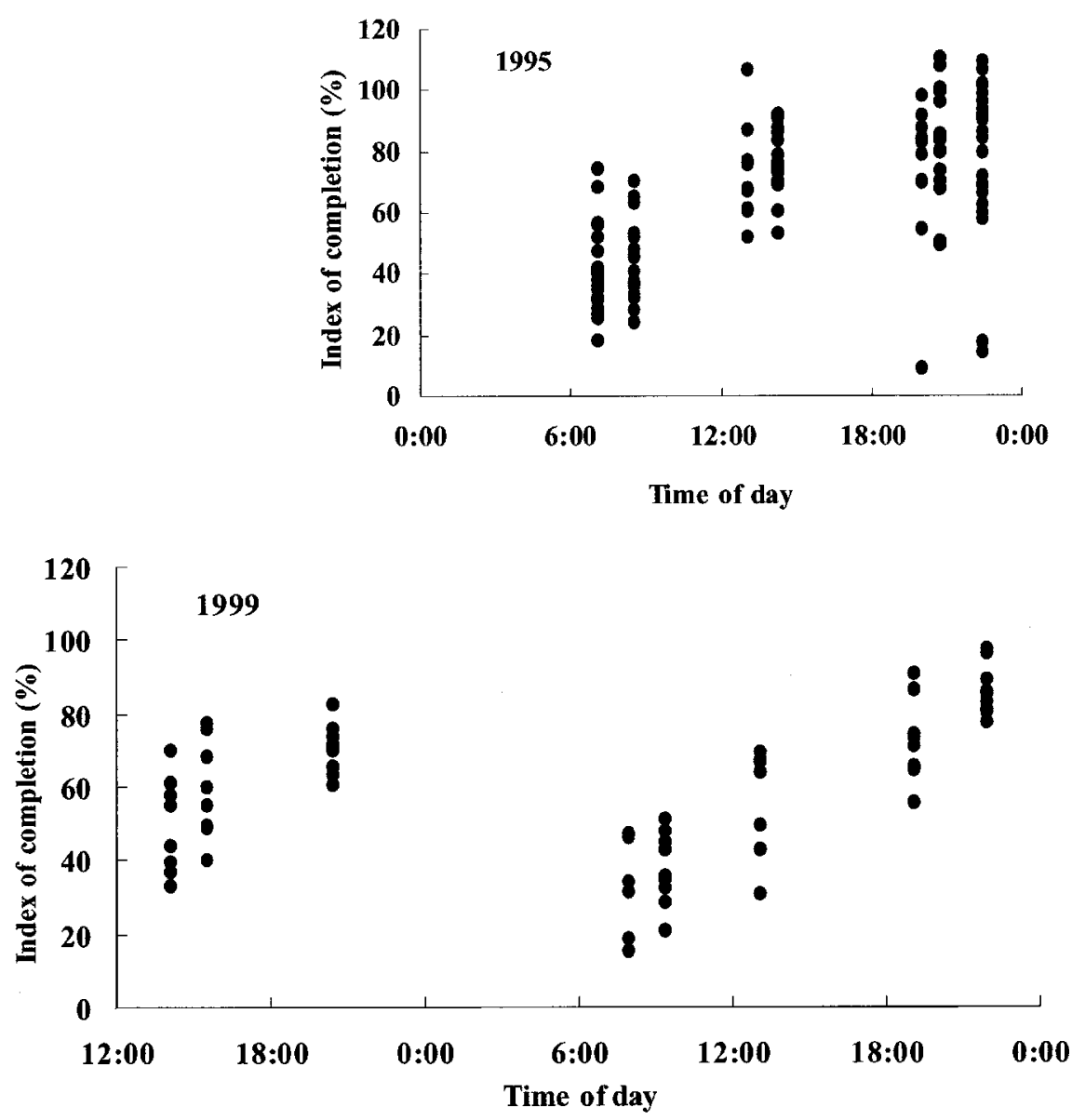

Fig. 3 Diel change in the index of completion of the marginal increment within otoliths of juvenile skipjack Katsuwonus pelamis. 

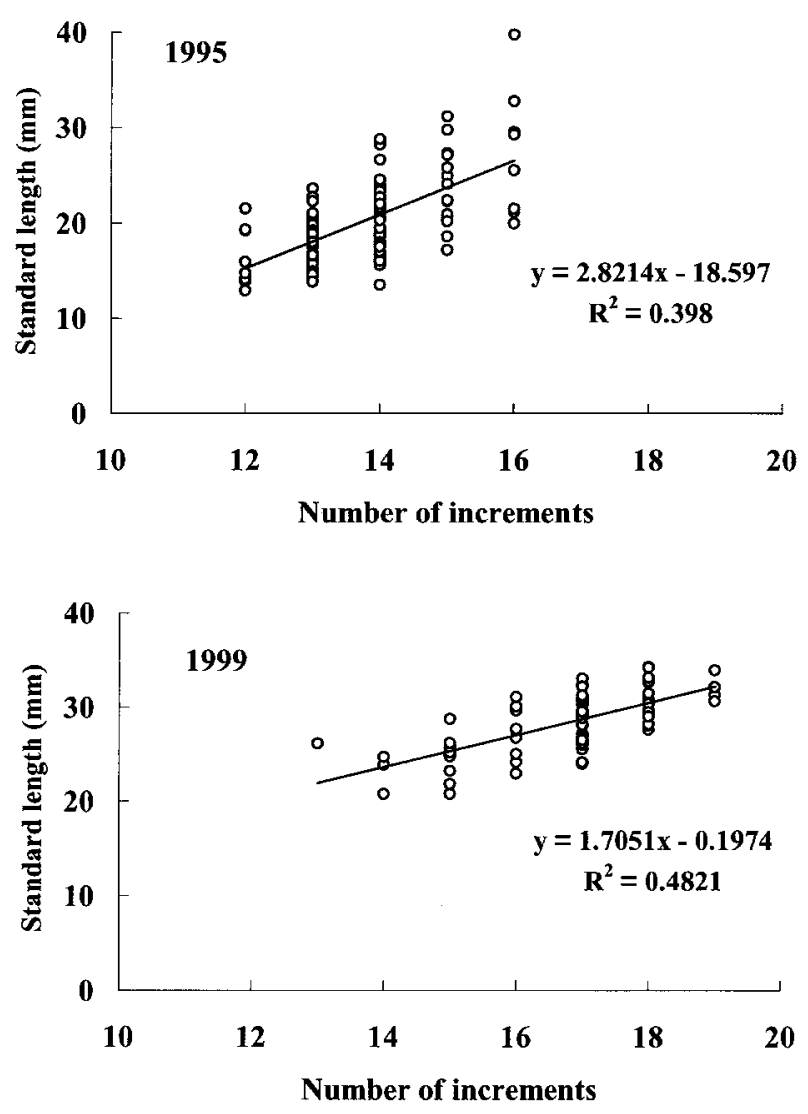

Fig. 4 Relationship between standard length ( $\mathrm{mm}$ ) and the number of increments within otoliths of juvenile skipjack Katsuwonus pelamis.

\section{DISCUSSION}

We conclude that daily growth increments are formed in the otoliths of juvenile skipjack tuna based on marginal increment analysis with time. In physiological and biochemical studies, a daily increment is formed by two different zones: one is an accretion zone that is predominantly aragonitic calcium carbonate and the other is a discontinuous zone composed of an organic matrix. ${ }^{14}$ Daily increment formation in otoliths has occurred with experimental photoperiodicity in a laboratory environment. ${ }^{15}$ In the daytime, from morning to afternoon, the activity of calcium carbonate deposition is high and results in the formation of an accretion zone. After sunset, the deposition of an organic matrix increases and results in the formation of a discontinuous zone. ${ }^{16}$ In the present study of juvenile skipjack tuna, the accretion zone, which is relatively wide, is deposited from early morning to afternoon, whereas the deposition of the discontinuous zone, which is relatively narrow, occurs during the evening of

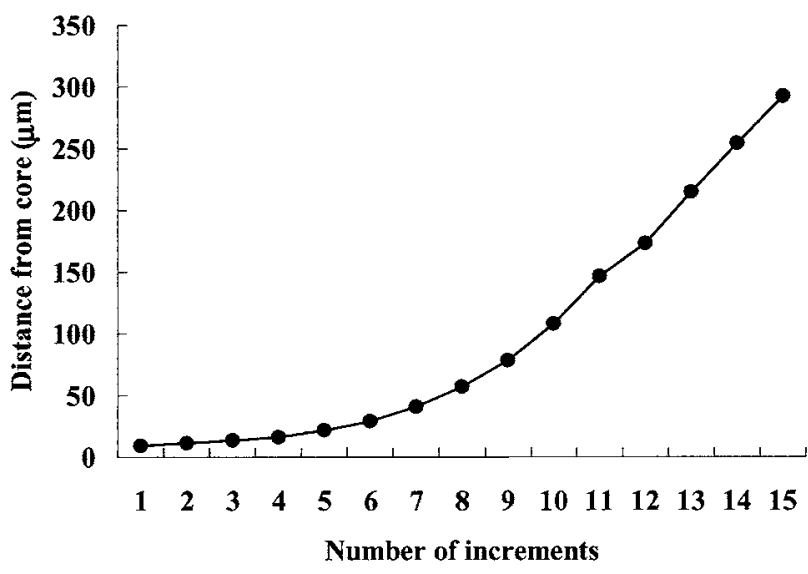

Fig. 5 Relationship between the number of daily increments and distance from the core in a sagittal otolith from a $29.8 \mathrm{~mm}$ standard length juvenile skipjack Katsuwonus pelamis.

each day. Thus, a new marginal increment is formed during the night. This diel progression of the marginal increment formation was similar between the 1995 and 1999 samples. Our study only presents evidence for daily increment deposition in the otoliths of juvenile skipjack, but does not address the apparent non-daily (approximately 0.7) increment formation in otoliths of adult skipjack tuna. ${ }^{11}$

The first daily increment was formed during the day after hatching (3 days after fertilization); ${ }^{9}$ therefore, the number of daily increments estimated in the present study could be used as an indication of age and growth of juvenile skipjack. The maximum daily growth rate of juvenile skipjack was approximately $3 \mathrm{~mm}$. The age of all specimens analyzed in the present study was less than 20 days after hatching, indicating rapid growth in the early life stage. The piscivorous food habit of skipjack tuna is revealed within the larval stage because the main prey organisms are fish larvae. ${ }^{17-20}$ We consider that this feeding habit contributes to the rapid growth during the early life stage of skipjack tuna. An extremely high growth rate was also reported in the case of Spanish mackerel Scomberomorus niphonius, which would be related to piscivory and early development of an adult-type digestive system. ${ }^{21}$

Variability in the index of completion of the marginal increment was large. Individual variation in the marginal increment formation among the same specimens was also reported for larval southern bluefin tuna Thunnus maccoyii, ${ }^{22}$ although there is no information about the marginal growth in otoliths of other tuna species during early life history. 
The increment width of sagittal otoliths in juvenile skipjack tuna increased from the core to the edge, especially after the 10th daily increment (Fig. 5). A few individuals had an index of marginal increment formation that was greater than $100 \%$. These data occur because of the increasing width of the marginal increment compared with that of the previous increment. The number of subdaily increments also increased with increasing increment width.

There is much information about the growth of skipjack tuna from previous studies; however, there are differences in results among scientists that may be primarily due to the use of different analytical methods. ${ }^{23}$ Therefore, a more reliable method for growth analysis of skipjack tuna should be established. The verification of daily increment formation within otoliths of juvenile skipjack contributes to estimating age and growth in this species, although additional studies of larval and adult stages are also necessary.

\section{ACKNOWLEDGMENTS}

We thank Captain T Nakajima and the crew of the FTV Omi Maru of Yamaguchi Fisheries High School for their assistance in conducting research cruises and the sampling of juvenile skipjack tuna. We are grateful to Dr T Kubota of Tokai University and Dr K Hayashizaki of Kitasato University for giving us helpful suggestions and also to Mrs M Takahashi of National Research Institute of Far Seas Fisheries (NRIFSF) and Mr F Yorozu of Tokai University for their assistance with preparing specimens and analyzing otoliths. We also thank Dr Y Uozumi of NRIFSF for critical review of the manuscript and Dr K Bigelow of National Marine Fisheries Service (NMFS) Honolulu laboratory for kindly improving the manuscript. This study was performed within the research on the distribution of juvenile skipjack tuna in the tropical western Pacific and financially supported by the Fisheries Agency of Japan.

\section{REFERENCES}

1. Campana S. Year-class strength and growth rate in young Atlantic cod Gadus morhua. Mar. Ecol. Prog. Ser. 1996; 135: 21-26.

2. Itoh T, Tsuji S. Age and growth of juvenile southern bluefin tuna Thunnus maccoyii based on otolith microstructure. Fish. Sci. 1996; 62: 892-896.

3. Meekan MG, Fortier L. Selection for fast growth during the larval life of Atlantic cod Gadus morhua on the Scotian Shelf. Mar. Ecol. Prog. Ser. 1996; 137: 25-37.
4. Stequert B, Panfili J, Dean JM. Age and growth of yellowfin tuna, Thunnus albacares, from the western Indian Ocean, based on otolith microstructure. Fish. Bull. 1996; 94: 124134.

5. Watanabe Y, Oozeki Y, Kitagawa D. Larval parameters determining preschooling juvenile production of Pacific saury (Cololabis saira) in the northwestern Pacific. Can. J. Fish. Aquat. Sci. 1997; 54: 1067-1076.

6. Anderson JT, Dalley EL. Interannual differences in hatching times and growth rates of pelagic juvenile cod in Newfoundland waters. Fish. Res. 2000; 46: 227-238.

7. Folkvold A, Blom G, Johannessen A, Moksness E. Growthdependent age estimation in herring (Clupea harengs L.) larvae. Fish. Res. 2000; 46: 91-103.

8. Zhang Z, Beamish RJ. Use of otolith microstructure to study life history of juvenile chinook salmon in the Strait of Georgia in 1995 and 1996. Fish. Res. 2000; 46: 239250 .

9. Radtke RL. Otolith formation and increment deposition in laboratory-reared skipjack tuna, Euthynnus pelamis, larvae. NOAA Tech. Rep. NMFS 1983; 8: 99-103.

10. Uchiyama JH, Struhsaker P. Age and growth of skipjack tuna, Katsuwonus pelamis, and yellowfin tuna, Thunnus albacares, as indicated by daily growth increments of sagittae. Fish. Bull. 1981; 79: 151-162.

11. Wild A, Wexler JB, Foreman TJ. Extended studies of increment deposition rates in otoliths of yellowfin and skipjack tunas. Bull. Mar. Sci. 1995; 57: 555-562.

12. Tanabe T, Niu K. Sampling juvenile skipjack tuna, Katsuwonus pelamis, and other tunas, Thunnus spp., using midwater trawls in the tropical western Pacific. Fish. Bull. 1998; 96: 641-646.

13. Gartner Jr JV. Life histories of three species of lanternfishes (Pisces: Myctophidae) from the eastern Gulf of Mexico. Mar. Biol. 1991; 111: 11-20.

14. Secor DH, Dean JM, Laban EH. Otolith removal and preparation for microstructural examination. In: Stevenson DK, Campana SE (eds). Otolith Microstructure Examination and Analysis. Can. Spec. Publ. Fish. Aquat. Sci. 1992; 117: 19-57.

15. Tanaka K, Mugiya Y, Yamada J. Effects of photoperiod and feeding on daily growth patterns in otoliths of juvenile Tilapia nilotica. Fish. Bull. 1981; 79: 459-466.

16. Mugiya Y. Phase difference between calcification and organic matrix formation in the diurnal growth of otoliths in the rainbow trout, Salmo gairdneri. Fish. Bull. 1987; 85: 395-401.

17. Aoki M. Feeding habits of larval and juvenile skipjack tuna. Bull. Inst. Ocean. Res. Dev. Tokai Univ. 1999; 20: 173-185.

18. Nishikawa Y. Feeding of larval and juvenile skipjack tuna in relation to the development of their stomachs. Bull. Far Seas Fish. Res. Lab. 1975; 12: 221-236.

19. Tanabe T. Feeding habits of skipjack tuna Katsuwonus pelamis and other tuna Thunnus spp. juveniles in the tropical western Pacific. Fish. Sci. 2001; 67: 567-570.

20. Young JW, Davis TLO. Feeding ecology of larvae of southern bluefin, albacore, and skipjack tunas (Pisces: Scombridae) in the eastern Indian Ocean. Mar. Ecol. Prog. Ser. 1990; 61: 17-29.

21. Tanaka M, Kaji T, Nakamura Y, Takahashi Y. Developmental strategy of scombrid larvae: High growth potential related to food habits and precocious digestive system develop- 
ment. In: Watanabe Y, Yamashita Y, Oozeki Y (eds). Survival Strategies in Early Life Stages of Marine Resources. AA Balkema, Rotterdam. 1996; 125-139.

22. Jenkins GP, Davis TLO. Age, growth rate, and growth trajectory determined from otolith microstructure of southern bluefin tuna Thunnus maccoyii larvae. Mar. Ecol. Prog. Ser. 1990; 63: 93-104.

23. Matsumoto WM, Skillman RA, Dizon AE. Synopsis of biological data on skipjack tuna, Katsuwonus pelamis. NOAA Tech. Rep. NMFS Circ. 1984; 451: 1-92. 